\title{
Drivers Of Customer Loyalty In A Retail Store Environment
}

\author{
Toyin A. Clottey, Ohio State University, USA
}

David A. Collier, Florida Gulf Coast University, USA

Michael Stodnick, University of North Texas, USA

\begin{abstract}
The determinants of customer loyalty are identified for a large U.S. retailer based on a survey of 972 customers. An ordered logistic regression is used to estimate the proportion of a retailer's customers who are willing to recommend the retailers products to others based on survey results. Statistical results document that service quality, product quality and brand image drive customer loyalty as measured by a customer's willingness to recommend the retailer's products to other people. Service management managers can improve these drivers of customer loyalty by better training, recognition and reward programs, day-to-day store operations, and job, product, process and store design. Given the general research objective of defining a universal model of what drives customer loyalty in a diverse set of industries, this research provides additional statistical evidence to support the theory that brand image, product quality, and service quality determine customer loyalty.
\end{abstract}

Keywords: Customer loyalty, service quality, product quality, brand image, ordered logistic regression

\section{INTRODUCTION}

everal authors examine the link between customer loyalty and long-term financial performance of a firm (Reichheld 1993, 2001; Jones and Sasser, 1995; Heskett et al., 1994), however, there has not been much agreement over the drivers or determinants of customer loyalty. For example, Heskett et al. (1994), in their conceptual model of the service-profit chain, believed that customer satisfaction was the driver of customer loyalty. Yet, Jones and Sasser (1995), provides examples of when customer satisfaction does not lead to loyal customers and found that brand image and product quality were more important drivers of customer loyalty. These diverse results can be partly explained by differing definitions of customer loyalty (De Ruyter et al., 1998; Baumann et al., 2005).

This research identifies three statistically significant determinants of customer loyalty and uses ordered logistic regressions to estimate the proportion of a retailer's customers who are willing to recommend the retailer's products to others. These findings are based on a survey of 972 customers of a large U.S retailer of women's apparel. The research hypotheses are stated as follows.

H1: Product quality is positively associated with customer loyalty.

H2: Service quality is positively associated with customer loyalty.

H3: Levels of brand image are positively associated with levels of customer loyalty.

We begin by briefly reviewing the literature, documenting the data set characteristics, and defining the ordered logistic regression model. We end by discussing the statistical results and how these models are used to estimate future sales, the value of a loyal customer, and where to best invest improvement dollars to increase customer loyalty. 


\section{LITERATURE REVIEW}

To support our research hypotheses and discussion of results we provide a brief review of the literature that relates to the following topics - service and product quality, brand image and customer loyalty.

\section{Service And Product Quality}

One of the most widely researched topics in service management is the concept of service quality. Three common service quality frameworks are the technical quality (what) versus functional quality (how) schema proposed by Gronroos (1984), the SERVQUAL framework proposed by Parasuraman et al $(1985,1988)$, and the SERVPERF framework proposed by Cronin and Taylor $(1992,1994)$. Since their inception, all three frameworks, or variations of them, have been used extensively in research and practical applications.

SERVQUAL is probably the most popular service quality framework. Its roots are in Oliver's (1980) disconfirmation model. Parasuramen et al (1985) assert that customers form global impressions of the quality of a service provider based on disconfirmation assessments of ten distinct dimensions: reliability, responsiveness, competence, access, courtesy, communication, credibility, security, understanding and tangibles. Later, Parasuramen et al (1988) reduce the ten construct dimensions to the following five dimensions: reliability, assurance, tangibles, empathy, and responsiveness. The SERVPERF framework (Cronin and Taylor, 1992) is a derivative of Parasuramen et al's SERVQUAL framework

The third service quality framework is the technical or functional quality framework proposed by Gronroos (1984). Technical quality refers to the technical outcome of the service, that is, "what the consumer receives as a result of his interactions with a service firm" -- the hotel guest will get a room; the restaurant patron will get a meal, etc. Functional quality corresponds to the expressive performance of a service, that is, how the service is performed. Functional quality is often called process quality and sometimes service quality.

The industry studied here is women's apparel - an industry where the physical good itself, in addition to the way in which it is provided, plays a very important role in creating customer loyalty. What Gronroos calls technical quality, this study will label product quality; what Gronroos calls functional quality, this study will label service quality. The specific survey items used to capture product quality are derived from Gronroos' items (1984, 1997). They are tailored to fit into a women's apparel setting. The specific survey items used to capture service quality draw on Parasuramen et al's $(1985,1988,1991)$ work. More specifically, we ask questions pertaining to four of their five dimensions: reliability, assurance, empathy and responsiveness. Tangibles include the physical goods for sale and the servicescape (Bitner, 1992).

\section{Brand Image}

Organizations work hard to build the brand image of their firm and its goods and services. Marketing processes such as advertising and sales attempt to create a long term commitment by the customer that increases brand awareness and repeat purchases, and therefore, customer loyalty. Superior day-to-day management of store operations also contributes to brand image, repeat purchases, and customer loyalty.

In the retail industry, customers' brand loyalty often outweighs their store loyalty. For example, this has been confirmed in the automobile industry by Bloemer and Jos (1992) and Huber and Herrmann (2001). Bloemer and Jos (1992), found a, statistically significant, positive relationship between brand loyalty and dealer loyalty in their regression model. They measured brand and dealer loyalty as repeat purchase intentions on a nine point scale. Huber and Herrmann (2001) measured brand and dealer loyalty as both repeat purchase intentions and willingness to recommend a dealer or brand using a 5 point scale. Their structural equation model confirmed a statistically significant positive relationship between brand loyalty and dealer loyalty. Their definition of dealer loyalty is similar to our definition of customer loyalty and their results suggest that brand image has a direct link to customer loyalty. 


\section{Customer Loyalty}

Zeithaml (2000) states that previous studies viewed customer loyalty as being either behavioral or attitudinal. The behavioral approach is that customers are loyal as long as they continue to buy and use a good or service (Woodside et al., 1989; Parasuraman et al., 1988; Zeithaml et al., 1996). Reichheld (2003) states that the strongest evidence of customer loyalty is the percentage of customers who were enthusiastic enough to refer a friend or colleague to a particular good and/or service. The attitudinal approach is that customers feel a sense of belonging or commitment to the good or service. Baumann et al. (2005) noted that Day (1969) four decades ago introduced the concept that loyalty has both behavioral and attitudinal dimensions.

The behavior approach includes criteria such as repeat purchase, share-of-wallet, and word of mouth referrals, whereas the attitudinal approach consists of criteria like commitment, trust or emotional attachment. Baldinger and Rubinson (1996) examined the link between attitude and behavior and found that 'the stronger the attitudinal commitment..., the more likely consumers were to remain loyal' thus the use of an attitudinal measure would also indicate the behavioral dimension of loyalty.

Smith and Wright (2004) used brand image, product quality, service quality, and firm viability in their structural equation model as direct determinants of customer loyalty to predict sales growth rate and return on assets in the personal computer industry. They used survey questions and data from PC World and PC Magazine. They found service quality and firm viability to be statistically significant but brand image was not and product quality was negatively associated with customer loyalty. Their definition of customer loyalty was PC Magazine's survey question "likely to buy again from this vendor." One of their conclusions is that "service quality--not product quality--differentiates competitors in the PC industry (Smith and Wright, 2004, p. 203).

Our research differs from the Smith and Wright's (2004) article in many ways such as i) their unit of measurement is firms; our unit of measurement is customers, ii) they used secondary data from consumer report magazines; we used data from a survey of real customers, iii) they did not use well established frameworks and scales to measure service quality but used the magazines questions; we used the SERVQUAL and SERVPERF framework and scales, iv) they measured customer loyalty as "likely to buy again from this vendor"; our measure is based on Reichheld's $(1993,2001)$ definition of customer loyalty and the survey question, "I recommend the retailer to my friends and family," and v) they modeled the long term viability and stability of PC firms; we did not use this construct since our firm is well established and a market leader.

The importance of brand image and product quality is also supported by the results of Hee-Su and Yoon (2004) who used a binary logistic model to determine that a mobile telephone subscriber would recommend the carrier to others. They allowed for a yes or no response to the customer loyalty question. Their statistical results found that call quality (service quality), customer mobile equipment type (product quality and features), and brand image were the variables that had significant (positive) effects on customer loyalty. Other variables they included in their model (e.g. age, sex and income) were not significant.

Our research differs from the Hee-Su and Yoon (2004) article in several ways such as (i) their service quality, product quality and brand image variables were binary variables based on customer satisfaction scores. The authors mention that a 5 point scale was used to obtain the satisfaction scores for each variable (Hee-Su and Yoon, 2004 , p. 758) but they do not explain how this 5 point scale was converted into a binary measurement for each variable. For instance, a 5 point scale for brand image would require 4 binary/dummy variables to represent this scale in a logistic regression but they only had one binary variable to represent brand image (ii) they mentioned that their choice of variables was based on "a survey questionnaire used by a leading mobile operator in Korea" (p. 759). Our choice of variables is based on a review of the literature.

Other research that supports our research hypotheses and design are as follows. Zeithaml et al., (1996) and Zeithaml, (2000) showed that perceived service quality influences customer behavioral intentions such as the intention to make repeat purchases. Based on survey data on telephone users in the UK, Ranaweera and Neely (2003) found that perceptions of service quality had a direct linear relationship with customer retention. Anderson 
and Mittal (2000) showed that the level of product quality influences whether a customer would recommend the firm's product via word-of-mouth advertising.

Our research extends past research in several ways. First, customer loyalty is measured by the customer's response to how strongly they would recommend the retailer to their friends and family on a seven point ordinal scale. This is different from Hee-Su and Yoon (2004) who modeled customer loyalty as a dichotomous yes or no response to the question of how strongly they would recommend the retailer to their friends and family. This is also different from Smith and Wright (2004) who used rating scores from PC Magazine on how likely a customer would repurchase from the firm. Our ordered logistic regression modeling approach allows the researcher or firm to maximize the information contained in the ordinal measured survey questions.

Second, brand image in this research is represented by the customer's perception of brand image on a seven point scale. Smith and Wright (2004) used the ratio of advertising expenditure to sales as a measure of brand image and Hee-Su and Yoon (2004) used a dichotomous yes or no variable to represent customer's perception of brand image.

Third, both Smith and Wright. (2004) and Hee-Su and Yoon (2004) used firms in technical markets (i.e. computers and mobile telephones) whereas this study uses data from a large women's apparel retailer. Due to the competitive nature of the PC industry, they used firm viability along with product quality, service quality, and brand image in their model. De Ruyter et al. (1998) cite several studies which show that industry type can influence customer loyalty, thus the relationships cited previously in the computer and telecommunication markets may differ in the women's apparel market. Together all of the research previously cited may find these three direct drivers of customer loyalty — product quality, service quality, and brand image - are universal and applicable to a wide range of industries.

\section{DATA CHARACTERISTICS}

The data for this study is from survey data collected and used by Stodnick (2005). The survey was administered to retail customers in ten randomly chosen districts in the U.S. The data originally consisted of 983 observations but 11 observations had missing values. Upon examination of the descriptive statistics for the data, there was no particular pattern to these missing observations therefore these observations were omitted from this study, leaving 972 usable observations. A rule of thumb is to have at least 10 to 15 observations for each unique parameter to be estimated (Hosmer and Lemeshow, 1989). Equation 4 has 15 parameters to be estimated, thus a sample size of 972 is adequate for the estimation of model parameters.

We use the same survey questions for the service quality and product quality constructs as Stodnick (2005). Table 1 gives the description of the questions used to measure service quality (SQ), product quality (PQ), brand image (BI) and customer loyalty (CL). Responses to each of the questions were recorded on a seven point scale. For the SQ and PQ constructs, the Cronbach coefficient alphas are identical to Stodnick (2005) research. Alpha values of 0.7 or higher are considered acceptable for providing statistical support that a single construct is being measured (Hair et al., 1995; Nunnally, 1978). The alpha values in Table 1 are all greater than 0.9 indicating that both SQ and PQ have construct validity. Since the CL and BI constructs are being measured by only one question (criterion), Cronbach coefficient alphas cannot be obtained for them. 
Table 1: Survey questions used to measure constructs

\begin{tabular}{|l|l|}
\hline \multicolumn{1}{|c|}{ LABEL } & DESCRIPTION \\
\hline Product Quality -PQ (a=0.9109) & Retailer offers merchandise of very high quality \\
\hline PQ1 & The quality of merchandise at retailer is higher than similar merchandise at other stores \\
\hline PQ2 & Retailers merchandise holds up well after repeated washings \\
\hline PQ3 & The merchandise I buy from this retailer is of consistent quality \\
\hline PQ4 & This retailers merchandise always meets my quality standards \\
\hline PQ5 & The quality of merchandise at this retailer consistently meets my expectations \\
\hline PQ6 & Retailer's associates have the skills necessary to help me \\
\hline Service Quality-SQ (a=0.9376) & I receive prompt service when I shop at this retailer \\
\hline SQ1 & Retailers associates give caring and individual attention \\
\hline SQ2 & Retailers associates are willing to go out of their way to help me \\
\hline SQ3 & Retailers associates are consistently courteous and friendly \\
\hline SQ4 & Retailers products have a very good brand image \\
\hline SQ5 & I recommend retailer to my friends and family \\
\hline Brand Image-BI & \\
\hline BI &
\end{tabular}

\section{ORDERED LOGISTIC REGRESSION MODEL}

We use ordered logistic regression to model a customer's choice of how strongly they would recommend the retailer to a family or friend on a seven point scale ( $\mathrm{i}=1$ is strongly disagree,..., 7 is strongly agree). The theory behind using this method to model customer choice is based on discrete choice theory in economics. Discrete choice theory is the study of behavior in situations where decision makers must select from a finite set of alternatives. It posits that an individual is likely to choose an alternative over others when the level of its utility to him/her is greater than the utility of other alternatives. The meaning of utility (usually thought to be synonymous with satisfaction) is not explicitly defined in the model, but it is assumed to be a function of observed attributes of the individual (and alternatives available to the individual) and this function takes a linear form (Cosslett, 1981). The validity of using discrete choice theory to model the continuous constructs underlying customer loyalty and brand image, consistent with attitude theory, has been addressed by Warshaw and Droge (1986) who linked utility theory in economics (i.e. discrete choices) to attitude theory in social psychology. Furthermore, the use of ordered logistic (or probit) regression to model the partial observation of an underlying continuous variable (customer loyalty in this case) was established in the statistics literature (Muthen, 1979).

In this research, the set of alternatives are the seven point scale responses $(i=1, \ldots, 7)$ to show how strongly a customer ( $\mathrm{j}$ ) would recommend the retailer to a family or friend. The observable attributes that influence this decision are the consumer's perception of product quality, service quality and brand image. The set consisting of these three attributes will be denoted by $V_{i j}$. A set of other, unobserved, attributes which could also affect the decision and this set is denoted by $e_{i j}$. The utility associated with a customer's (j) decision to choose alternative (i) is denoted by $U_{i j}$ and is expressed as:

$U_{i j}=V_{i j}+e_{i j}$

The probability that the $\mathrm{jth}$ customer chooses response $\mathrm{i}(\mathrm{i}=1, \ldots, 7)$ vs an alternative response $\mathrm{k}(\mathrm{k}=1, \ldots, 7 ; \mathrm{i} \neq \mathrm{k})$ is given by the probability that $U_{i j}>U_{k j}$ as shown below:

$P_{i j}=\operatorname{Pr}($ customer $\mathrm{j}$ chooses response $\mathrm{i})=\operatorname{Pr}\left(U_{i j}>U_{k j}\right)$ 
For the ordered logistic regression model, the unobserved attributes are assumed to be independent random variables with a common (identical) logistic distribution ${ }^{1}$. These assumptions (also, assuming i>k) allow the above probability (Equation 2) to be expressed as follows:

$$
P_{i j}=F\left(V_{i j}\right)-F\left(V_{k j}\right)=F\left(X \beta_{i}\right)-F\left(X \beta_{k}\right)
$$

Where, $X$ is a matrix of explanatory variables, $\beta_{i}$ and $\beta_{k}$ are vectors of coefficients to be estimated for choices i and $\mathrm{k}(\mathrm{i}>\mathrm{k})$, respectively. $\mathrm{F}(\bullet)$ represents the cumulative logistic distribution function. If we add the assumption that the odds in each of the $i=1, \ldots 7$ categories are proportional ${ }^{2}$, we can model the cumulative probability that a customer will choose either of the responses up to and including the kth response $(\mathrm{k}=2, \ldots 7)$ using the following ordered logistic expression shown in Equation 4:

$\log i t(\operatorname{Pr}($ Loyalty $\leq k \mid$ Customer $=j))=\log \left(\frac{p_{1 j}+p_{2 j}+\ldots+p_{k j}}{1-\left(p_{1 j}+p_{2 j}+\ldots+p_{k j}\right)}\right)=\alpha_{k}+\beta_{1} S Q+\beta_{2} P Q+\sum_{s=2}^{7} \beta_{3 s} B I_{s}[4]$

Modeling the probability that a customer would lie in any of the seven categories, is equivalent to estimating the proportion, of all the customers of the retailer, that lie in each ordinal category ranging from 1 to 7. Table 2 summarizes the descriptions of the notations in Equation 4. Model diagnostics are performed to ensure that there are no violations of the underlying assumptions of the model.

Table 2: Notation definitions for equation 4

\begin{tabular}{|l|l|l|}
\hline Notation & Name & Description \\
\hline Pr(Loyalty $\leq \mathrm{k} \mid$ customer $=\mathrm{j})$ & & $\begin{array}{l}\text { Probability that customer } \mathrm{j} \text { selects any response up to and } \\
\text { including } \mathrm{k}(\mathrm{k}=1, \ldots, 7)\end{array}$ \\
\hline$P_{i j}$ & Probability that customer $\mathrm{j}$ chooses response $\mathrm{i}$ \\
\hline $\mathrm{SQ}$ & Service Quality & Factor Scores for service quality \\
\hline $\mathrm{PQ}$ & Product Quality & Factor Scores for product quality \\
\hline$B I_{s}(\mathrm{~s}=2, \ldots, 7)$ & Brand Image & $\begin{array}{l}\text { Indicator variables for various levels of customer response to } \\
\text { brand image question }\left(B I_{s}=1 \text { if customer chooses response }\right. \\
\text { s for brand image question; }=0 \text { otherwise })\end{array}$ \\
\hline$\alpha_{i}(\mathrm{i}=2, . ., 7)$ & Estimated intercept for category $\mathrm{i}-1$ to $\mathrm{i}$ \\
\hline$\beta_{l}(\mathrm{l}=1,2)$ & Intercept & Estimated Slope coefficients for SQ and PQ respectively \\
\hline$\beta_{3 s}(\mathrm{~s}=1, \ldots, 6)$ & Slope Coefficients & Estimated coefficients for brand image indicators. \\
\hline
\end{tabular}

\footnotetext{
${ }^{1}$ The logistic distribution is used when there are several extreme responses. This is a valid assumption in this study since there are several respondents who chose a 1 or a 7 response making the tails, of the error term distribution, fatter than a standard normal distribution would allow which invalidates the use of a probit model. In order not to confuse this type of model with the usual probit model, a distinction is made by Agresti (2002), calling it the "ordered logistic regression" model.

${ }^{2}$ The changing intercept term in Equation (4) can be thought of as representing the ordering and the constant slope parameters as representing the proportionality of the odds. The ordered logistic model in the form of Equation (4) is estimated by many statistical software packages (e.g. SAS and SPSS) and is valid when the assumption of proportional odds has not been grossly violated. See Agretsi (2002) for details of the derivation supporting these assumptions and conclusions.
} 


\section{RESULTS}

The factor loadings for the SQ and PQ constructs are shown in Table 3 and were obtained using the principal components extraction method. Items that loaded heavily on particular factors are in bold type in Table 3. The two factors explain $69 \%$ of the variance in the items. All items, for each factor, have loadings greater than 0.5 indicating unidimensionality is supported by the high loadings on each factor. Also each factor has an eigen value greater than one meaning that the factor is not redundant with the previously extracted factors. Tables 4 and 5 show the descriptive statistics for the categorical variables (CL and BI) and the quantitative variables (z-scores for SQ and PQ), respectively. Since there are observations at each level of the categorical variables, parameter estimates can be obtained for all the parameters in Equation 4 as shown in Table 6. Note that SQ and PQ constructs are standardized factor scores and also the BI construct is represented by six indicator variables, thus the resulting regression model using these variables is equivalent to a standardized regression model as no scale changes can be practically applied to the model. This is important in interpreting the results as this allows for the coefficients to be compared in both magnitude and direction.

Table 3: Factor loadings for SQ and PQ constructs*

\begin{tabular}{|c|c|c|}
\hline & SQ & PQ \\
\hline SQ1 & $\mathbf{0 . 7 4}$ & 0.229 \\
\hline SQ2 & $\mathbf{0 . 8 2 8}$ & 0.164 \\
\hline SQ3 & $\mathbf{0 . 9 3}$ & 0.17 \\
\hline SQ4 & $\mathbf{0 . 8 9 5}$ & 0.16 \\
\hline SQ5 & $\mathbf{0 . 8 2 9}$ & 0.198 \\
\hline PQ1 & 0.2 & $\mathbf{0 . 7 4 4}$ \\
\hline PQ2 & 0.173 & $\mathbf{0 . 5 8 5}$ \\
\hline PQ3 & 0.13 & $\mathbf{0 . 7 6 7}$ \\
\hline PQ4 & 0.18 & $\mathbf{0 . 8 5 2}$ \\
\hline PQ5 & 0.231 & $\mathbf{0 . 8 6}$ \\
\hline PQ6 & 0.221 & $\mathbf{0 . 8 1 6}$ \\
\hline Eigen Values & 3.857 & 3.754 \\
\hline
\end{tabular}

*Items that loaded heavily on particular factors are in bold.

* Extraction Method: Principle Component.

*Rotation Method: Varimax with Kaiser Normalization.

Table 4: Descriptive statistics for $C L$ and BI categorical constructs

\begin{tabular}{|c|c|c|}
\hline \multirow{8}{*}{ CL } & Levels & Frequency \\
\hline & 1 & 6 \\
\hline & 2 & 7 \\
\hline & 3 & 18 \\
\hline & 4 & 81 \\
\hline & 5 & 114 \\
\hline & 6 & 275 \\
\hline & 7 & 471 \\
\hline \multirow{8}{*}{ BI } & Levels & Frequency \\
\hline & 1 & 3 \\
\hline & 2 & 2 \\
\hline & 3 & 1 \\
\hline & 4 & 29 \\
\hline & 5 & 86 \\
\hline & 6 & 333 \\
\hline & 7 & 518 \\
\hline
\end{tabular}


Table 5: Descriptive statistics for $S Q$ and $P Q$ constructs (factor scores)

\begin{tabular}{|c|c|c|c|}
\hline \multicolumn{2}{|c|}{ SQ } & \multicolumn{2}{|c|}{ PQ } \\
\hline Min. & -5.34 & Min. & -4.96 \\
\hline 1st Qu. & -0.484 & 1st Qu. & 0.467 \\
\hline Median & 0.164 & Median & 0.226 \\
\hline Mean & $-2.28 \mathrm{E}-16$ & Mean & $2.71 \mathrm{E}-16$ \\
\hline 3rd Qu. & 0.828 & 3rd Qu. & 0.620 \\
\hline Max. & 2.68 & Max. & 3.11 \\
\hline
\end{tabular}

Table 6: Equation 4 model parameter estimates

Model coefficients

\begin{tabular}{|c|c|c|c|c|}
\hline & Value & Std. Error & t value & p-value \\
\hline SQ & 0.63885 & 0.070906 & 9.00981 & $0.000^{* *}$ \\
\hline PQ & 0.871733 & 0.08266 & 10.54598 & $0.000^{* *}$ \\
\hline BI.2 & -1.76772 & 1.578484 & -1.11989 & 0.141 \\
\hline BI.3 & -11.658 & 166.9701 & -0.06982 & 0.472 \\
\hline BI.4 & 2.422648 & 1.121427 & 2.160325 & $0.024^{*}$ \\
\hline BI.5 & 2.780664 & 1.086873 & 2.558407 & $0.011^{*}$ \\
\hline BI.6 & 2.788975 & 1.084425 & 2.571847 & $0.011^{*}$ \\
\hline BI.7 & 3.783912 & 1.09292 & 3.462204 & $0.002^{* *}$ \\
\hline
\end{tabular}

*significant at $5 \%$ level $(p<0.05)$; ** significant at $1 \%$ level $(p<0.01)$

Model intercepts

\begin{tabular}{|c|c|c|c|c|}
\hline & Value & Std. Error & t value & p-value \\
\hline $1 \mid 2$ & -3.3379 & 1.102 & -3.0289 & $0.009^{* *}$ \\
\hline $2 \mid 3$ & -2.3587 & 1.0621 & -2.2209 & $0.043^{*}$ \\
\hline $3 \mid 4$ & -1.223 & 1.0726 & -1.1401 & 0.272651 \\
\hline $4 \mid 5$ & 0.549 & 1.0856 & 0.5057 & 0.622305 \\
\hline $5 \mid 6$ & 1.6563 & 1.086 & 1.5252 & 0.149999 \\
\hline $6 \mid 7$ & 3.4171 & 1.0851 & 3.1492 & $0.004 * *$ \\
\hline
\end{tabular}

*significant at $5 \%$ level $(p<0.05)$;** significant at $1 \%$ level $(p<0.01)$

Table 7: Estimated response probabilities when SQ and $P Q$ are at their median values

\begin{tabular}{|c|c|c|c|c|c|c|c|}
\hline & \multicolumn{9}{|c|}{ Probabilities } \\
\hline Brand Image & $\mathbf{C L = 1}$ & $\mathbf{C L = 2}$ & $\mathbf{C L}=\mathbf{3}$ & $\mathbf{C L}=\mathbf{4}$ & $\mathbf{C L}=\mathbf{5}$ & $\mathbf{C L}=\mathbf{6}$ & CL=7 \\
\hline BI=7 & 0.000571 & 0.000947 & 0.003193 & 0.022374 & 0.050617 & 0.251186 & $\mathbf{0 . 6 7 1 1 1 2}$ \\
\hline BI=4 & 0.002223 & 0.003673 & 0.012234 & 0.079836 & 0.149399 & 0.409207 & 0.343429 \\
\hline BI=1 & 0.024452 & 0.038105 & 0.109463 & $\mathbf{0 . 3 7 7 9 3 7}$ & 0.237191 & 0.168431 & $\mathbf{0 . 0 4 4 4 2 2}$ \\
\hline
\end{tabular}

The first step in evaluating the model is to check for violations of the underlying assumptions. The proportional odds assumption was first examined by using the likelihood ratio test. This tests whether the effects (slope coefficients) are the same for each cumulative logit against the alternative of separate effects. It compares the proportional odds model as depicted by Equation 4, with a more complex model with different slope parameters for each cumulative logit. If the proportional odds assumption is valid, then the more complex model should not fit better than the proportional odds model and therefore the null hypothesis that both models fit equally well should not be rejected (Agresti, 2002). The p-value for the null hypotheses $\left(\mathrm{H}_{\mathrm{o}}\right.$ : Proportional Odds) is 0.413 with a Chi square of $41.32(\mathrm{df}=40)$ which is strong statistical evidence in support of the null. Thus the proportional odds assumption is valid. 
In order to assess how well the model fits the data, the McFadden (1974) Pseudo- $\mathrm{R}^{2}$ was computed. The pseudo- $\mathrm{R}^{2}$ measure for the model is $17.2 \%$ which indicates that the explanatory power of the model is superior to that of the constant probability model. A likelihood ratio test, similar to the one used to test the proportional odds assumption above, was conducted to compare the equal probability model to our estimated model. The test had a pvalue of less than $1 \%$ which shows that there is a statistically significant difference between the models. This indicates that the pseudo- $\mathrm{R}^{2}$ value is significant and thus the model is a good fit to the data.

Partial residual plots were examined for any departures from linearity (see Agresti, 2002). These plots did not show a pattern indicative of any gross departures from the linearity assumption. Also plots of the deviance residuals (Agretsi 2002) were examined for any evidence of lack-of-fit. Again, these plots did not show patterns indicative of any lack-of-fit. All of these results suggest that the ordered logistic model fits the data very well, the model's assumptions are valid, and the interpretation of the estimates in Table 6 can proceed.

\section{Hypothesis 1: Product Quality}

Hypothesis $1\left(\mathrm{H}_{1}\right)$ predicts that if a customer perceives that the retailer's products are of a high quality, then that customer will likely recommend the retailer to family and friends. $\mathrm{H}_{1}$ is supported in Table 6 since the PQ coefficient is positive and statistically significant at the $1 \%$ level. The odds interpretation of the PQ coefficient is that a unit increase in the PQ score, would increase the odds that a customer would respond in the strongly agree direction rather than the strongly disagree direction, to the customer loyalty question, by a factor of 2.39 $\left(=e^{(0.87173 \nexists)}\right)$, holding all other variables in the model constant. The coefficient estimate of PQ is +0.871733 in Table 6. Therefore, increases in the customer's perception of product quality leads to an increase in the likelihood that the customer would respond in the strongly agree direction to the customer loyalty question; holding service quality and brand image constant.

\section{Hypothesis 2: Service Quality}

Hypothesis $2\left(\mathrm{H}_{2}\right)$ predicts that if a customer perceives that the retailer's service is of high quality, then that customer will likely recommend the retailer to family and friends. $\mathrm{H}_{2}$ is supported in Table 6 since the SQ coefficient is +0.63885 and statistically significant at the $1 \%$ level. The odds interpretation of the SQ coefficient is that a unit increase in the SQ score, would increase the odds that a customer would respond in the strongly agree direction rather than the strongly disagree direction, to the customer loyalty question, by a factor of 1.89 $\left(=e^{(0.63885)}\right)$, holding all other variables in the model constant. Therefore, increases in the customer's perception of service quality leads to an increase in the likelihood that the customer would respond in the strongly agree direction to the customer loyalty question; holding product quality and brand image constant.

\section{Hypothesis 3: Brand Image}

Hypothesis $3\left(\mathrm{H}_{3}\right)$ predicts that high brand image awareness by a customer would increase the likelihood that the customer will recommend the retailer to family and friends. Table 6 shows that the coefficients for all of the high brand image responses (i.e. $\mathrm{BI}=4,5,6$ and 7) are statistically significant at the 5\% significance level and have positive signs. Furthermore, the coefficients increase in magnitude with increasing levels of BI, thus higher levels of brand image awareness have larger positive effects on customer loyalty. This result supports $\mathrm{H}_{3}$.

Using the odds interpretation of the coefficients, the estimate of $\mathrm{BI}=7$ indicates that the estimated odds that a customer who strongly agrees that the retailer's brand has a good image, would also respond in the strongly agree direction, to the customer loyalty question, is $44\left(=e^{(3.783912}\right)$ times the odds of a customer who strongly disagrees that the retailers brand has a good image (i.e. $\mathrm{BI}=1$ ); holding service quality and product quality constant. Similar interpretations apply to the other BI coefficients in the model and Table 6.

The magnitudes of the coefficients of all the high brand image responses (i.e. BI = 4, 5, 6 and 7) are larger than the coefficients of both SQ and PQ. This indicates that, in this retail environment, a customer's perception of a 
good brand image has more of a positive effect on their loyalty to the retailer's product, than their perceptions of product or service quality alone. For example, using the odds interpretation of the coefficients, the odds of a loyal customer for strong brand image awareness (i.e. $\mathrm{BI}=7)$ is $18.4\left(=e^{(3.783912-0.871733)}\right)$ times that for product quality $(\mathrm{PQ})$ and $23.2\left(=e^{(3.783912-0.63885)}\right)$ times that for service quality (SQ).

Table 7, shows estimated probabilities for each of the categories of customer loyalty (CL), given low, medium and high levels of brand image awareness (i.e. BI $=1,4$ or 7 respectively). Interpretations of the proportions highlighted in bold type in Table 7 are as follows: At an average (median) level of perceived service and product quality, an estimated $67 \%$ of the retailer's customers, who strongly agree that the retailer has a good brand image $(\mathrm{BI}=7)$, would also strongly agree to recommend the retailer's products to family and friends. At the other end $(\mathrm{BI}=1)$, only $4 \%$ of customers who strongly disagree that the retailer has a good brand image would strongly agree to recommend the retailer's products to family and friends. About $38 \%$ of those who strongly disagree that the retailer has a good brand image $(B I=1)$ would give a neutral response $(C L=4)$ when asked if they would recommend the retailer's products to family and friends.

\section{PRACTICAL APPLICATIONS}

The regression model can be used to estimate the proportion of the retailer's customers who would recommend the retailer's products to family and friends. This information can help managers identify and target improvement categories and help justify the allocation of resources to brand image development and service and product quality performance.

A few example ways to use the results documented in Tables 6 and 7 are as follows. Table 7 shows that $45 \%(0.237+.168+0.044)$ of customers who are not aware of the brand image of the retailer (i.e. $\mathrm{BI}=1)$, would recommend the retailer's products to family and friends. Whereas $97 \%(0.051+0.251+0.671)$ of customers who are highly aware of the brand image of the retailer (i.e. $\mathrm{BI}=7$ ), would recommend the retailer's products to family and friends. Thus assuming that each customer who agrees to recommend the product to family and friends, does recommend it to exactly one other person, the retailer stands to gain $53(97-44=53)$ additional customers for every 100 customers the retailer is able to make highly aware of their brand. Figure 1 is a graph of the results documented in Table 7. These types of insights are inputs into computing the value of a loyal customer; identify where to best spend a firm's improvement funds, and forecasting future sales and customer retention rates.

Also, the retailer could also decide to invest in improving other determinants of customer loyalty such as service quality if the potential gain of a $1 \%$ loyalty increase in the $\mathrm{BI}=1$ category is larger than a $1 \%$ loyalty increase in the $\mathrm{BI}=7$ category, since loyal customers in the $\mathrm{BI}=1$ category are loyal because of either product or service quality and not brand image awareness.

In addition, Ennew and Binks (1996) note that it is difficult to measure behavioral intentions such as customer retention compared to more attitudinal intentions such as customer loyalty, thus the use of attitudinal loyalty measures can help to better estimate more difficult (behavioral) retention. Retention rates are then used by Rust et al. (1995, p. 61) to obtain estimates of current and future period market shares (i.e. aggregate sales forecasts) from historical market share and market size data, to be used in their return on quality equation. 
Figure 1: Bar Chart of estimated proportions at median levels of service quality and product quality

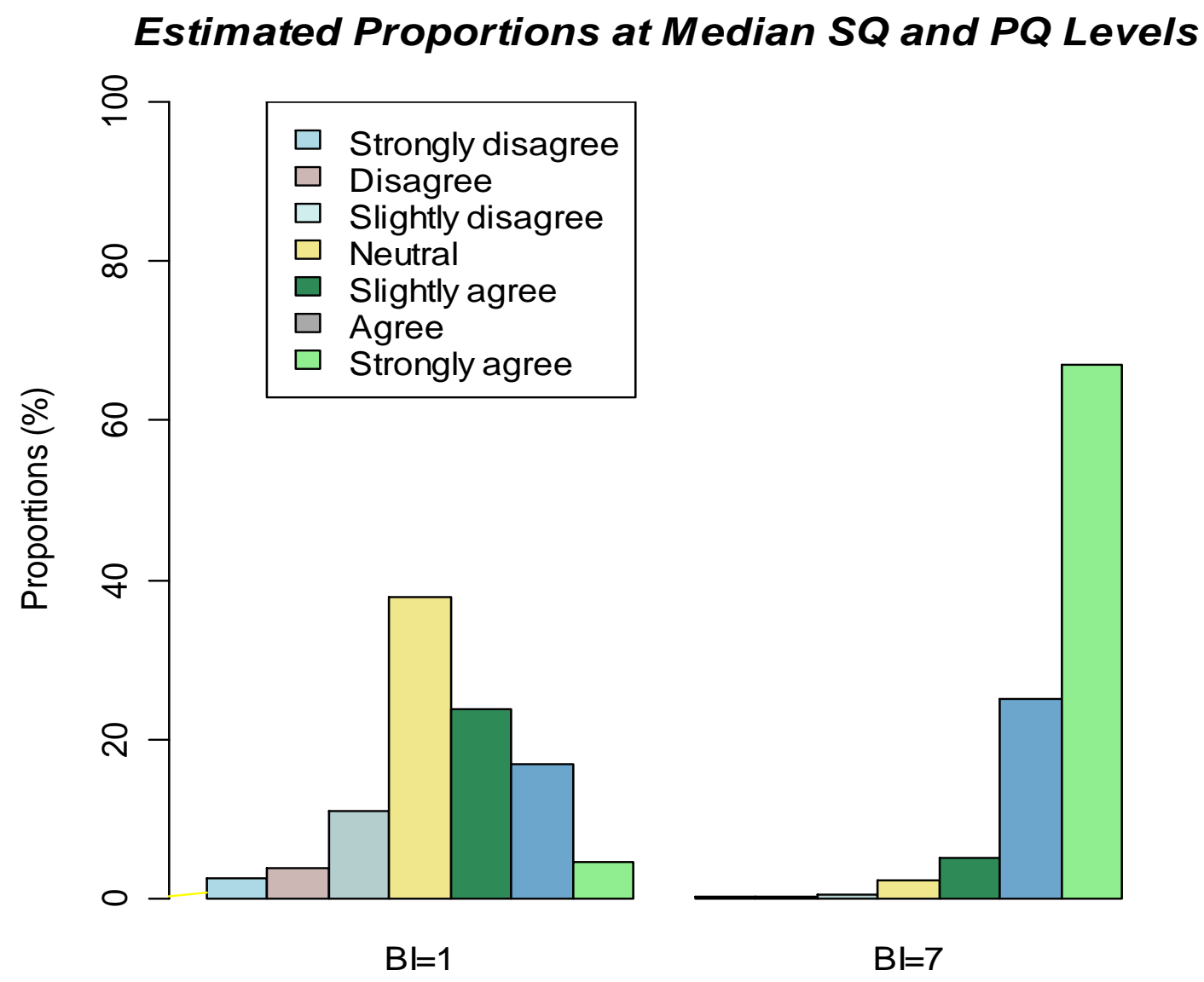

\section{CONCLUSIONS AND RESEARCH EXTENSIONS}

An ordered logistic regression model supported the three hypotheses that product quality, service quality, and brand image are drivers of customer loyalty in a retail setting based on a sample of 972 customers. Brand image was the strongest driver of customer loyalty followed by product quality then service quality. These models can help managers predict sales and customer retention rates, compute the value of a loyal customer, and provide guidance as to where to best spend improvement funds such as better product quality, service-provider training, advertising, upgrading the store servicescape, and job and process design (Collier and Evans, 2009).

Future research could extend the study to other markets to see if these statistical results are also applicable in different industries. If so, and based on the previous research cited here, we collectively may have found a universal model for explaining customer loyalty in a wide variety of industries.

\section{REFERENCES}

1. Agresti, A. (2002) Categorical Data Analysis $2^{\text {nd }}$ Edition, John Wiley and Sons Inc, Hoboken, NJ

2. Anderson, E., and Mittal, V. (2000) Strengthening the satisfaction-profit chain Journal of Service Research, Vol. 3, November, p107-120. 
3. Baldinger, A.L. and Rubinson, J. (1996) Brand loyalty: the link between attitude and behavior, Journal of Advertising Research, 36(6): 22-34.

4. Baumann, C., Burton, S. and Elliott, G. (2005), Determinants of Customer Loyalty and Share of Wallet in Retail Banking, Journal of Financial Services Marketing, Vol. 9, No.3, p231-48.

5. Bitner, M. (1992). Servicescapes: The impact of physical surroundings on customers and employees. Journal of Marketing, 56(2), 57-71.

6. Bloemer, J M.M.; Jos G.A.M. L. (1992) The Importance of Customer Satisfaction in Explaining Brand and Dealer Loyalty Journal of Marketing Management Vol. 8, p351-364, 14p.

7. Collier, D.A. and Evans, J.R. (2009) OM, South-Western Cengage Learning, 5191 Natrrop Boulevard, Mason, Ohio, www.4ltrpress.cengage.com/om, (ISBN: 978-0-324-66255-9), Chapter 6 and 7.

8. Cosslett, S. R. (1981), Efficient estimation of discrete-choice models. In C. F. Manski, \& D. McFadden (Eds.), Structural Analysis of Discrete Data with Economic Applications Cambridge, MA: The MIT Press.

9. Cronbach, L. (1951). Coefficient alpha and internal structure of tests. Psychometrika, 16, 297 - 334.

10. Cronin, J. and Taylor, S. (1992). Measuring service quality: A reexamination and extension. Journal of Marketing, 56 (3), $55-68$.

11. Cronin, J. and Taylor, S. (1994). SERVPERF versus SERVQUAL: Reconciling performance-based and perceptions-minus-performance measurements of service quality. Journal of Marketing, 58 (1), 125 - 131.

12. Day, G. (1969) A two-dimensional concept of brand loyalty, Journal of Advertising Research, Vol. 9, No 3, pp. 29-35.

13. De Ruyter, K, Wetzels. M, and Bloemer. J (1998), On the Relationship between Perceived Service Quality, Service Loyalty and Switching Costs, International Journal of Service Industry Management, 9, p436.

14. Dick, A. S.and Basu, K. (1994) Customer Loyalty: Toward an Integrated Conceptual Framework; Journal of the Academy of Marketing Science; Vol. 22, p99-113, 15p.

15. Ennew, C. T. and Binks, M. R. (1996) The impact of service quality and service characteristics on customer retention: Small businesses and their banks in the UK, British Journal of Management, Vol. 7, No.3, pp. 219-230.

16. Gronroos, C. (1984) A service quality model and its marketing implications European Journal of Marketing, Vol. 18, No.4, p36-44.

17. Gronroos, C. (1997). From marketing mix to relationship marketing: Towards a paradigm shift in marketing. Management Decision, 35 (4), 322 - 339.

18. Gronroos, C. (1997). Value-driven relational marketing: From products to resources and competencies. Journal of Marketing Management, 13 (5), 407 - 419.

19. Hair, J., Andeson, R., Tatham R. and Black, W. (1995) Multivariate Data Analysis, $5^{\text {th }}$ Edition” Prentice hall, Englewood cliffs, N.J.

20. Heskett, J. L., Jones, T.O., Loveman, T.W., Sasser, Jr., W.E. and Schlesinger, L. (1994) Putting the serviceprofit chain to work, Harvard Business Review 72 (2): 164-174.

21. Hee-Su. K and Yoon, C.H (2004), Determinants of Subscriber Churn and Customer Loyalty in the Korean Mobile Telephony Market, Telecommunications Policy, Vol. 28 No. 10, Oct./Nov., p751-765.

22. Huber, F and Herrmann, A. (2001) Achieving Brand and Dealer Loyalty: The Case of the Automotive Industry, International Review of Retail, Distribution and Consumer Research, 11, April, p97-122.

23. Jones, T. O. and Sasser, Jr., W.T. (1995) Why satisfied customers defect Harvard Business Review, November-December, p88-99.

24. McFadden, D. (1974) Conditional Logit Analysis of Qualitative Choice Behavior, in P. Zarembka (ed.), Frontiers In Econometrics, 105-142, Academic Press: New York, 1974.

25. Muthén, Bengt (1979), A Structural Probit Model with Latent Variables, Journal of the American Statistical Association, 74 (12), 807.

26. Nunnally, C. (1978) Psychometric Theory McGraw-Hill, New York, NY.

27. Oliver, R. L. (1980) A Cognitive Model of the Antecedents and Consequences of Satisfaction Decisions, Journal of Marketing Research, Vol.17, November, pp.460-9.

28. Parasuraman, A., Zeithaml, V., and Berry, L. (1985). A conceptual model of service quality and its implications for future research. Journal of Marketing, 49 (4), $41-50$.

29. Parasuraman, A., Zeithaml, V., and Berry, L. (1988). SERVQUAL: A multiple-item scale for measuring consumer perceptions of service quality. Journal of Retailing, 64 (1), $29-40$. 
30. Parasuraman, A., Zeithaml, V. A. and Berry, L.L. (1991) Refinement and reassessment of the SERVQUAL instrument Journal of Retailing, Vol. 67, No. 4, p420-450.

31. Ranaweera, C. and Neely, A. (2003), Best Student Paper some Moderating Effects on the Service QualityCustomer Retention Link, International Journal of Operations \& Production Management, Vol. 23, p230248.

32. Reichheld, F. F. (1993) Loyalty-Based Management. Harvard Business Review, March-April, p64-73.

33. Reichheld, F. F. (2001) Lead for loyalty Harvard Business Review, July-August, p76-85.

34. Reichheld, F.F (2003) The One Number You Need to Grow, Harvard Business Review, December, p485491.

35. Rust, R. T.; Zahorik, A. J.; and Keiningham, T. L. (1995), Return on quality (ROQ): Making service quality financially accountable, Journal of Marketing, Vol. 59, No. 2 (April), pp. 58-70.

36. Rust,R. T.,K einingham,T . L.,Clemens ,S . \& Zahorik,A. J. (1999) Return on quality at Chase Manhattan Bank, Interfaces, 29,pp . 62-72.

37. Stodnick, M.A (2005) Driving Retail Store Performance: A Service Profit Chain Perspective, Dissertation, The Ohio State University.

38. Smith, R. E. and Wright, W.F. (2004), Determinants of Customer Loyalty and Financial Performance, Journal of Management Accounting Research, 16, p183-205.

39. Warshaw, Paul R. and Cornelia Dröge (1986), Economic Utility Versus the Attitudinal Perspective of Consumer Choice, Journal of Economic Psychology, 7 (03), 37.

40. Woodside, A,G., Frey, L. L, Daly, R. T (1989) Linking Service Quality, Customer Satisfaction, and Behavioral Intention, Journal of Health Care Marketing, Vol. 9, December, p5-17.

41. Zeithaml, V. A., Berry, L. L. and Parasuraman, A. (1996) The Behavioral Consequences of Service Quality, Journal of Marketing, Vol. 60, April, p31-46.

42. ZeithamI, V. A. (2000) Service Quality, Profitability, and the Economic Worth of Customers: What we know and what we don't know, Journal of the Academy of Marketing Science, Vol. 28 , No. 1, p67-85. 
NOTES 